\title{
Phytochemical Screening and Antibacterial Potentiality of Essential Oil from Psoralea corylifolia Linn.
}

\author{
Sharmishtha Purkayastha and Praveen Dahiya
}

\begin{abstract}
Psoralea corylifolia Linn. (Leguminoseae) known as "Babchi" is a medicinal plant for the treatment of skin disorders. In the present investigation babchi essential oil has been evaluated for phytochemical constituents, antibacterial activity (agar well diffusion) and TLC bioautography assay. Phytochemical analysis demonstrated the presence of flavonoids, tannins, steroids, terpenoids, glycosides and saponins. Antibacterial activity of babchi oil was assessed on eight multi-drug resistant (MDR) clinical isolates from both Gram-positive and Gram-negative bacteria and two standard strains. It showed broad antibacterial activity against both Gram-positive bacteria such as Staphylococcus aureus, S. aureus MRSA, Enterococcus sp. and Gram-negative bacteria Escherichia coli, Pseudomonas aeruginosa, Klebsiella pneumoniae. The highest in vitro inhibitory activity was observed for MDR Enterococcus sp. with wide inhibition zone diameters $(21 \pm 0.16 \mathrm{~mm})$ followed by standard S. aureus ATCC $25923(16 \pm 0.11 \mathrm{~mm})$ and $K$. pneumoniae $(15 \pm 0.056 \mathrm{~mm})$. Thin layer chromatography and bioautography assay demonstrated well-defined growth inhibition zones against Enterococcus sp. in correspondence with tannins observed at $R f$ values of 0.10 0.15 and $0.70-0.83$. This established a good support to the use of this essential oil in herbal medicine and as a base for the development of novel potent drugs and phytomedicine. To the best of our knowledge, this is the first report that documents the antibacterial efficacy of tannins found in babchi essential oil against MDR bacteria from clinical isolates.
\end{abstract}

Index Terms-Psolarea corylifolia, Agar well diffusion, MULTI-drug resistant, TLC bioautography, antibacterial activity

\section{INTRODUCTION}

Antimicrobial resistance is a global problem that has created immense clinical problem in treatment of infectious diseases. The clinical efficacy of many existing antibiotics is being threatened by the emergence of multidrug-resistant (MDR) pathogens. Hospitals, worldwide are major contributors of the problem of antimicrobial resistance [1]. Hospital-acquired infections are expensive to control and extremely difficult to eradicate. It is estimated that about 70 per cent of the bacteria that cause infections in hospitals are resistant to at least one of the drugs most commonly used for treatment. Looking at this scenario there is a continuous and urgent need to discover new antimicrobial compounds with diverse chemical structures and novel mechanisms of action for new and re-emerging infectious diseases. In India, antimicrobial resistance has been reported in for the most predominant pathogenic microorganisms including $S$.

Manuscript received March 30, 2012; revised May 22, 2012.

The authors are with Amity Institute of Biotechnology, Amity University, Noida, Uttar Pradesh, India (e-mail: praveen_sang@yahoo.com). aureus, Enterococcus faecalis, Mycobacterium tuberculosis and $P$. aeruginosa. Medicinal plants form an integral component of research in the pharmaceutical industry focusing on active screenings of natural products to develop better drugs against microbial infections. Essential oils (also called volatile oils) are aromatic oily liquids obtained from plant materials (flowers, buds, seeds, leaves, twigs, bark, herbs, wood, fruits and roots). The oil can be obtained by expression, fermentation or extraction. Steam distillation is the most commonly used method for commercial production. Essential oils are a rich source of biologically active compounds. Hence, there has been an increased interest in looking at antimicrobial properties of extracts from aromatic plants particularly essential oils.

Psoralea corylifolia Linn. Belonging to family Leguminoseae is a well known herb known for its medicinal value in Siddha system of medicines to treat various diseases. Commonly known as babchi, this is an erect annual herb grown in dry and arid land bearing yellow or bluish purple flowers and found throughout Indian plains, Pakistan, Srilanka, Burma and China [2]. Psoralea is one of the main herbs in traditional Indian and Chinese herbal medicine for the treatment of skin disorders. It has been used in the treatment of eczema and hair loss. Roots of the plant are useful in dental caries, fruits are laxative, aphrodisiac, and are used for the treatment of leucoderma, leprosy and in inflammatory diseases of the skin and leaves are good for the treatment of diarrhea $[3,4,5]$. The plant has been used in Ayurvedic medicinal system as a cardiac tonic, vasodilator and pigmentor. It is widely used in Chinese medicine to treat a variety of diseases and possesses antitumor, antibacterial, cytotoxic and antihelmenthic properties [6, 7]. Medicinal value of plants lies in the presence of chemical substances that produce a definite physiological action on the human body. The most important bioactive compounds include alkaloids, flavonoids, tannins and phenolic compounds. Thus plants extracts and plant compounds could serve as alternatives in anti-infective therapy of diseases caused by multidrug resistant organisms.

Despite possessing wide applicability, babchi has not received much attention and no research on phytochemical screening and TLC bioautography for babchi essential oil has been studied till date. The present study relates to phytochemical screening, antibacterial potentiality and TLC bioautography assay against multi-drug resistant (MDR) Gram-positive (Methicillin-resistant Staphylococcus aureus and Enterococcus sp.) and Gram-negative (Klebsiella sp., Escherichia coli, Pseudomonas aeruginosa and Acinetobacter sp.) bacterial strains isolated from human infections. 


\section{MATERIALS AND METHODS}

\section{A. Acquisition of oil of Psoralea corylifolia}

Commercial brand of Psoralea corylifolia essential oil (Babchi oil) was purchased from Delhi, India. As per manufacturer's information, it was prepared by steam distillation. The oil was further distilled by rotary evaporator. Essential oil was dissolved in methanol $(0.3 \mathrm{ml}$ oil/ $2 \mathrm{ml}$ methanol). The oil was transferred into sterile vials and stored at $-20 \mathrm{C}$ until needed.

\section{B. Microbial Strain and Growth Conditions}

MDR clinical isolates of Staphylococcus aureus, S.aureus MRSA, Escherichia coli, Kleibsella pneumoniae, Pseudomonas aeruginosa, Enterococcus sp., Acinetobacter sp. and Proteus mirabilis were obtained from the Department of Microbiology, Rajiv Gandhi Cancer Research Institute, Delhi, India. The test strains were maintained on nutrient agar slants (Hi-Media Laboratories Pvt. Limited, Mumbai, India) at $4{ }^{\circ} \mathrm{C}$ and sub-cultured on to nutrient broth for $24 \mathrm{~h}$ prior to testing. These bacteria served as test pathogens for antibacterial activity assay. Standard strains Staphylococcus aureus ATCC 25923 and Escherichia coli ATCC 25922 were used for quality control.

\section{Phytochemical Screening}

Babchi essential oil dissolved in methanol $(0.3 \mathrm{ml}$ oil $/ 2$ $\mathrm{ml}$ methanol) was evaluated for the presence of different phytochemicals to ascertain the presence of metabolites such as reducing sugars, alkaloids, anthraquinones, glycosides, flavonoids, tannins, steroids, saponins, triterpenoids and phlobatanins by using wet reactions following the procedures described by Sofowora [8] and Trease and Evans [9].

\section{Antibacterial Activity Assay}

Antibacterial activity of Psolarea corylifolia essential oil was determined by agar well diffusion method according to National Commmittee for Clinical Laboratory Standards [10]. About $25 \mathrm{ml}$ of Nutrient agar medium was poured into each petri plate. Once the agar solidified, the bacteria were inoculated on the surface of the plates $\left(1 \times 10^{8}\right.$ $\mathrm{CFU} / \mathrm{ml})$. Subsequently, wells $(8 \mathrm{~mm}$ in diameter) were punched into the agar medium and filled with $50 \mu \mathrm{l}$ of oil in methanol and allowed to diffuse at room temperature for $2 \mathrm{~h}$. The plates were incubated at $37^{\circ} \mathrm{C}$ for $24 \mathrm{~h}$. The well containing the same volume of methanol served as negative control while standard antibiotic discs of Imepenem $(10 \mu \mathrm{g})$ and Vancomycin $(30 \mu \mathrm{g})$ were used as the positive controls. After incubation, the diameters of the growth inhibition zones were measured in millimeters. All tests were performed in triplicate and the antibacterial activity was expressed as the mean of inhibition with their standard deviation.

\section{E. TLC Bioautography Assay}

A thin layer chromatography (TLC) bioautographic agaroverlay method [11] was used to analyze components in babchi essential oil as well as the most bio-active phytoconstituent (as antibacterial agent). About $10 \mu \mathrm{l}$ of oil in methanol was applied on pre-coated aluminium silica gel G 25 plates. The plates were developed with toluene and ethyl acetate $(93: 7 \mathrm{v} / \mathrm{v})$. The TLC plates were run in triplicate. One of the strips was visualized under UV light to see if the separated spots were UV active after which it was sprayed with $2 \%$ vanillin sulphuric acid reagent, the second strip was used for bioautography assay and the third strip was used to identify spots with the various TLC reagents to detect the presence of flavonoids, saponins and tannins. To detect the presence of flavonoids, plates were sprinkled with a $5 \%$ aluminum chloride $\left(\mathrm{AlCl}_{3}\right)$ ethanolic solution. Yellow or greenish fluorescent spot confirms flavonoids. Saponins were observed by the appearance of blue, violet and yellow spots using $10 \%$ vanillin ethanol solution. Tannins were observed by the presence of bluish or greenish black after revelation with a $2 \%$ ferric chloride solution as described by Johanne et al. [12]. Individual $R \mathrm{f}$ for each spot was measured. TLC bioautography was carried out using the selected strains of bacteria. The developed TLC plates were thinly overlaid with molten nutrient agar inoculated with an overnight culture of bacteria. The plates were incubated in a dark and humid chamber overnight at $37^{\circ} \mathrm{C}$. Subsequently, the bioautogram was sprayed with an aqueous solution of 2 , 3, 5 triphenyl tetrazolium chloride and further incubated for at $37^{\circ} \mathrm{C}$ for $4 \mathrm{~h}$. Microbial growth inhibition appeared as clear zones against a pink background. The $R f$ values of the spots showing inhibition were determined.

\section{RESULTS AND DiSCUSSION}

\section{A. Phytochemical Analysis}

TABLE I: PHYTOCHEMICAL ANALYSIS OF PSORALEA CORYLIFOLIA (BABCHI OIL)

\begin{tabular}{|l|c|}
\hline \multicolumn{1}{|c|}{ Phytoconstituents } & Babchi Oil \\
\hline Reducing Sugar & - \\
\hline Tannins & + \\
\hline Glycosides & + \\
\hline Saponins & + \\
\hline Flavonoids & + \\
\hline Steroids & + \\
\hline Anthraquinone & - \\
\hline Terpenoids & + \\
\hline Phlobatanins & + \\
\hline Flavonosides & + \\
\hline
\end{tabular}

a) +: Positive, b) -: Negative

Preliminary phytochemical screening of babchi essential oil showed that the essential oil contain most of the phytochemicals (Table 1) including tannins, glycosides, saponins, flavonoids, steroids, terpenoids and flavonosides. However, anthraquinone, phlobatanins and reducing sugars were not observed in babchi oil. Similar results were reported where phytochemical screening of Psoralea corylifolia seeds reveals that the major constituents present were coumarins and flavonoids, and other constituents were steroids and triterpenoids [6]. On the contrary, saponins and tannins were found to be absent as reported by Gidwani et al., 2011 [6]. Phenolic compounds like tannins are potent inhibitors of many hydrolytic enzymes used by plant 
pathogens. Somasundaram et al. [13] reported the presence of saponins, tannins, flavonoids, glycosides, carbohydrates, tannins and phenolic compounds, gums and mucilages, fixed oils and fats in Psoralea corylifolia leaf extracts.

\section{B. Antibacterial Activity Assay}

The microorganisms were obtained from the Department of Microbiology, Rajiv Gandhi Cancer Research Institute, Delhi, India along with their resistant profile (Table 2). Psoralea corylifolia (babchi oil) was screened for potential antibacterial activity against MDR bacteria by agar well diffusion method. Gram-negative strains Proteus mirabilis and Acinetobacter sp. did not show any antibacterial activity when tested with babchi oil, the remaining MDR bacteria exhibited moderate to high susceptibility (Table 3). However, many researchers reported Gram-negative bacteria to be more susceptible than Gram- positive bacterial strains [14], [15] whereas, high susceptibility of Gram-positive bacteria was reported by Kiran et al., [16] and Chanda and Barawalia, [17]. Gram-negative strains Proteus mirabilis and Acinetobacter sp. did not show any antibacterial activity when tested with babchi essential oil, the remaining MDR bacteria exhibited moderate to high susceptibility. Furthermore, the highest activity was observed for MDR Enterococcus sp. with wide inhibition zone diameters $(21 \pm 0.16 \mathrm{~mm})$ followed by standard $S$. aureus ATCC $25923(16 \pm 0.11 \mathrm{~mm})$ and Klebsiella pneumoniae $(15 \pm 0.056 \mathrm{~mm})$. In another study, Upadhayay et al., [18] reported significant antibacterial potential of babchi oil against Lactobacillus acidophilus, Streptococcus pneumoniae and Micrococcus luteus. Similarly, high susceptibility was reported for methanolic extract of essential oil was reported for a number of tested grampositive and gram negative bacterial isolates by Chanda $e t$ al., [19] and Dahiya et al., [20]. Moderate antifungal activity for Psolarea corylifolia seed extract against pathogenic fungal strains was reported by Jamil et al., [21]. The negative control plate did not exhibit inhibition on the tested bacteria where as standard antibiotics Imepenem and Vancomycin produced significantly larger inhibition zones against Gram-negative and Gram-positive bacteria respectively. In the present study, babchi essential oil tested has shown strong antibacterial potential against both Grampositive and Gram-negative pathogenic bacteria.

TABLE II: ANTIBIOTIC RESISTANCE PROFILE OF VARIOUS GRAM-POSITIVE AND GRAM-NEGATIVE

\begin{tabular}{|c|c|c|c|c|c|c|c|}
\hline \multicolumn{8}{|c|}{ BACTERIAL ISOLATES USED } \\
\hline Antibiotics & $K p$ & & $P a$ & $S a$ & Sa MRSA & Asp. & Esp. \\
\hline $\mathbf{A K}$ & S & S & S & $\mathrm{S}$ & $\mathrm{S}$ & $\mathrm{R}$ & $\mathrm{R}$ \\
\hline $\mathbf{A C}$ & $\mathrm{R}$ & $\mathrm{R}$ & $\mathrm{R}$ & $\mathrm{S}$ & $\mathrm{R}$ & $\mathrm{R}$ & $\mathrm{R}$ \\
\hline CFX & $\mathrm{R}$ & $\mathrm{R}$ & $\mathrm{R}$ & $\mathrm{R}$ & $\mathrm{R}$ & $\mathrm{R}$ & $\mathrm{R}$ \\
\hline CS & $\mathrm{R}$ & $\mathrm{S}$ & S & S & $\mathrm{S}$ & $\mathrm{R}$ & $\mathrm{R}$ \\
\hline CE & $\mathrm{R}$ & $\mathrm{R}$ & $\mathrm{R}$ & S & $\mathrm{R}$ & $\mathrm{R}$ & $\mathrm{R}$ \\
\hline CI & $\mathrm{R}$ & $\mathrm{R}$ & $\mathrm{R}$ & $\mathrm{R}$ & $\mathrm{R}$ & $\mathrm{R}$ & $\mathrm{R}$ \\
\hline $\mathbf{C F}$ & $\mathrm{R}$ & $\mathrm{R}$ & S & $\mathrm{R}$ & $\mathrm{R}$ & $\mathrm{R}$ & $\mathrm{R}$ \\
\hline G & S & $\mathrm{R}$ & S & S & $\mathrm{R}$ & $\mathrm{R}$ & $\mathrm{R}$ \\
\hline I & $S$ & $\mathrm{~S}$ & $\mathrm{~S}$ & S & $\mathrm{S}$ & $\mathrm{R}$ & $\mathrm{R}$ \\
\hline LE & S & $\mathrm{R}$ & $S$ & $S$ & $\mathrm{~S}$ & $\mathrm{R}$ & $\mathrm{R}$ \\
\hline MR & S & S & $S$ & S & $\mathrm{R}$ & $\mathrm{R}$ & $\mathrm{R}$ \\
\hline OF & $\mathrm{R}$ & $\mathrm{R}$ & $S$ & $\mathrm{R}$ & $\mathrm{R}$ & $\mathrm{R}$ & $\mathrm{R}$ \\
\hline VA & - & - & - & S & $\mathrm{S}$ & S & S \\
\hline
\end{tabular}

AK: Amikacin, AC: Amoxycillin/Clavulanic acid, CFX: Cefixime, CS: Cefoperazone+ Sulbactum, CE: Cefotaxime,

CI: Ceftriaxone, CF: Ciprofloxacin, G: Gentamicin, I: Imipenem, LE: Levofloxacin, MR: Meropenem, OF: Ofloxacin,

VA: Vancomycin, R: Resistant, S: Sensitive, Kp: Klebsiella pneumoniae, Ec: Escherichia coli, Sa: Staphylococcus aureus,

Pa: Pseudomonas aeruginosa, Asp: Acinetobacter sp., Esp: Enterococcus sp.

\section{TLC Bioautography Assay}

Bioautographic assay is usually used to screen for antimicrobial activity by separating components onto the surface of chromatographic plates and overlaying the TLC plate with molten bacterial agar. TLC bioautography were performed for Psolarea corylifolia oil against Enterococcus sp. and Klebsiella pneumoniae. Bioautography showed presence of one or more active compounds at different $R f$ values. Inhibition zones against the growth of Enterococcus sp. were observed on the TLC plates as white spots on pink background when sprayed with aqueous solution of 2, 3, 5 triphenyl tetrazolium chloride. Inhibitory zones with $R f$ values of $0.10-0.15$ and $0.70-0.83$ on plate $B$ for Enterococcus sp. (shown in fig 1) and one small inhibitory zone with $R f$ value of $0.12-0.15$ for Klebsiella pneumoniae (not shown) corresponds to the spots representing tannins on plate $\mathrm{C}$ which was positive with $2 \% \mathrm{FeCl}_{3}$ spray solution (Fig 1). Hence, our results suggest that the strong antibacterial activity against Enterococcus sp. present in Psolarea corylifolia (babchi) oil may be due to the presence of tannins. These findings corroborated with the 
observations of Hatano et al., [22] who reported the antibacterial efficacy of tannins against $S$. aureus MRSA. The observed inhibition on the TLC bioautographic plate was likely due to one or more active compounds which overlap possibly due to the solvent system used for separation.

TABLE III: ANTIBACTERIAL ACTIVITY OF BABCHI ESSENTIAL OIL DETERMINEd By AGAR WeLl DifFusion METHOD

\begin{tabular}{|l|c|}
\hline \multicolumn{1}{|c|}{ Test Bacteria } & Zone of Inhibition (in mm) \\
\hline Staphylococcus aureus & $12 \pm 0.09$ \\
\hline Staphylococcus aureus MRSA & $11 \pm 0.13$ \\
\hline S. aureus ATCC 25923 & $16 \pm 0.11$ \\
\hline Escherichia coli & $12.5 \pm 0.08$ \\
\hline E. coli ATCC 25922 & $14 \pm 0.10$ \\
\hline Enterococcus sp. & $21 \pm 0.16$ \\
\hline Pseudomonas aeruginosa & $10.5 \pm 0.07$ \\
\hline Klebsiella pneumoniae & $15 \pm 0.056$ \\
\hline Proteus mirabilis & - \\
\hline Acinetobacter sp. & - \\
\hline
\end{tabular}

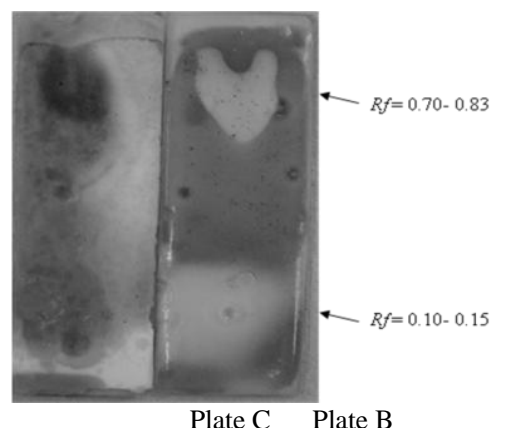

Fig. 1. Chromatogram for Tannin (Plate C) and Bioautogram (Plate B) for Babchi essential oil against Enterococcus sp. Plate $\mathrm{C}$ arrow indicates tannin spots visualized when sprayed with $2 \%$ ferric chloride solution. Zones of inhibition (Plate B) are observed as clear spots against pink background. Mobile phase: Toluene/Ethyl acetate (93:7 v/v)

\section{CONCLUSION}

This study emphasizes antimicrobial properties of essential oil of Psolarea corylifolia against human MDR bacteria. This is the first report on phytochemical screening and bioautography of babchi oil possessing antibacterial activity against many Gram positive and Gram-negative bacteria. The antibacterial activity of babchi oil against Enterococcus sp is due to the presence of tannins which has been validated employing TLC bioautography assay. The essential oil of Babchi have shown excellent activity against Enterococcus sp, Pseudomomas aeruginosa, E. coli and $S$. aureus and is the potential candidates to be developed into next generation of antimicrobials to combat multidrug resistance (MDR) in pathogenic microorganisms.

\section{ACKNOWLEDGEMENT}

I acknowledge profound gratitude to Dr. Charu Aggrawal,
Department of Microbiology, Rajiv Gandhi Cancer Research Institute, Delhi, India for providing clinical isolates of MDR bacteria. The author is also thankful to Amity Institute of Biotechnology, Amity University, Noida, U.P, India for offering facilities to carry out this study.

\section{REFERENCES}

[1] World Health organization (WHO), "Antimicrobial Resistance fact sheet," no. 194, 2002.

[2] K. R. Kirtikar and B. D. Basu, Indian Medicinal Plants.2nd ed. Mahendra publication, pp. 718, 1994.

[3] P. K. Mukherjee, Quality Control of Herbal Drugs.1st ed, Business Horizon Pharmaceutical Publishers, pp. 600, 2002.

[4] V. D. Rangari and S. R. Agrawal, "Chemistry and Pharmacology of Psolarea corylifolia," Indian Drugs, vol. 29, pp. 662, 1992.

[5] V. Rajpal, Standardization of Botanicals, 2nd ed. Eastern Publisher, pp. 284, 2005.

[6] P. S. Khushboo, V. M. Jadhav, and V. J. Kadam, "Development and validation of a HPTLC method for determination of psoralen in Psoralea corylifolia (Bavachi) ," Intl. J. PharmTech. Res vol. 1, no. 4, pp. 1122-1128, 2009.

[7] B. Gidwani, R. N. Alsapure, and N. J. Duragkar, "Pharmacognostic and standardization and physico-chemical evaluation of Psoralea corylifolia linn seeds," Imperial J. Pharmacog.Natural Prod, vol. 1, no. 1. pp. 145-151, 2011.

[8] A. Sofowora, "Medicinal Plants and Traditional Medicine in Africa," 2nd ed. Ibadan (Nigeria): Spectrum Books Ltd, pp. 289, 1993.

[9] G. E. Trease and W. C. Evans, Pharmacognosy, 13thed. London (UK): ELBS Oxford University Press, pp. 245-263, 1989.

[10] NCCLS, Performance Standards for Antimicrobial Disc Suspectibility Tests. Approved Standard NCCLS Publication M2- A5, Villanova, PA, USA, 1993.

[11] C. Alagesaboopathi, "Antimicrobial potential and phytochemical screening of Andrographis affinis nees -anendemic medicinal plant from India," Intl. J. Pharmacy Pharmaceu. Sci., vol. 3, no. 2, pp. 157159,2011

[12] S. Johann, M. Pizzolatti, C. L. Donnici, and M. A. Resende, "Antifungal properties of plants used in Brazilian traditional medicine against clinically relevant fungal pathogens," Braz J Microbiol, vol. 38 , no. 4, pp. 117-20, 2007.

[13] T. Somasundaram, H. B. Chandrashekhar, M. Bhanumati, and R. V. Amritraj, "Phytochemical investigation and antimicrobial studies on the leaf extracts of Psoralea corylifolia Linn.," Pharmacog Journal, vol. 2, no. 5, pp. 11-15, 2010.

[14] D. Shahwar and A. R. Muhammad, "In vitro antibacterial activity of extracts of Mimusops elengi against gram positive and gram negative bacteria," Afr. J. Microbiological Res, no. 3, pp. 458-462, 2009.

[15] N. V. Enwuru, S. O. Ogbonnia, F. Nkemehule, C. A. Enwuru and O. Tolani, "Evaluation of antibacterial activity and acute toxicity of the hydroethanolic extract of Stachytarpheta angustifolia (Mill) Vahl," Afr. J. Biotechnol, no. 7, pp. 1740-1744, 2008.

[16] S. R. Kiran, P. Sita and K. J. Reddy, "Evaluation of in vitro antimicrobial activity leaf and stem essential oils of Chloroxylon swietenia ," Dc. World J. Microbiol. Biotech, vol. 24, pp. 1909-1914, 2008.

[17] S. Chanda and Y. Barawalia, "Screening of some plant extracts against some skin diseases caused by oxidative stress and microorganisms," Afr. J. Biotechnol, no. 9, pp. 3210-3217, 2010.

[18] P. Dahiya and S. Purkayastha, "Phytochemical analysis and antibacterial efficacy of Dill seed oil against multi-drug resistant clinical isolates," Asian J. Pharmaceutical and Clinical Research, vol. 5, no. 2, 2012.

[19] R. K. Upadhyay, P. Dwivedi, and S. Ahmad, "Screening of antibacterial activity of six plant essential oils against pathogenic bacterial strains," Asian J.Med. Sci, vol. 2, no. 3, pp. 152-158, 2010.

[20] S. Chandra, M. Kanwria, and R. Nair, "Antibacterial activity of Psolarea corylifolia L. seed and aerial parts with various extraction methods," Res. J. Microbio, vol. 6, no. 2, pp. 124-131, 2011.

[21] A. Jamil, M. Shahid, M. M. U. H. Khan, and M. Ashraf, "Screening of some medicinal plants for isolation of antifungal proteins and peptides," Pak. J. Bot, vol. 39, no. 1, pp. 211-221, 2007.

[22] T. Hatano, M. Kusuda, K. Inada, T. Ogawa, S. Shiota, and T. Tsuchiya, "Effects of tannins and related polyphenols on methicillinresistant Staphylococcus aureus, Phytochemistry," vol. 66, no. 17, pp. 2047-2055, 2005. 